\title{
Perspectives in Diagnosis and Treatment of Rabies Viral Encephalitis: Insights from Pathogenesis
}

\author{
Anita Mahadevan ${ }^{1}$ (D) $\cdot$ M. S. Suja ${ }^{1} \cdot{\text { Reeta S. } \text { Mani }^{2} \cdot \text { Susarala K. Shankar }}^{1}$
}

Published online: 20 June 2016

(C) The American Society for Experimental NeuroTherapeutics, Inc. 2016

\begin{abstract}
Rabies viral encephalitis, though one of the oldest recognized infectious disease of humans, remains an incurable, fatal encephalomyelitis, despite advances in understanding of its pathobiology. Advances in science have led us on the trail of the virus in the host, but the sanctuaries in which the virus remains hidden for its survival are unknown. Insights into host-pathogen interactions have facilitated evolving immunologic therapeutic strategies, though we are far from a cure. Most of the present-day knowledge has evolved from in vitro studies using fixed (attenuated) laboratory strains that may not be applicable in the clinical setting. Much remains to be unraveled about this elusive virus. This review attempts to re-examine the current advances in understanding of the pathobiology of the rabies virus that modulate the diagnosis, treatment, and prevention of this fatal disease.
\end{abstract}

Keywords Rabies $\cdot$ Neurovirulence $\cdot$ Apoptosis $\cdot$ Negri bodies $\cdot$ Pathogenesis $\cdot$ Survival

\section{Introduction}

Rabies is one of the oldest and most dreaded of human diseases. It continues to be a major public health problem in developing countries. An acute, fatal encephalitis, it is caused

Anita Mahadevan

mahadevananita@gmail.com

1 Department of Neuropathology, National Institute of Mental Health \& Neurosciences, Bangalore 560 029, India

2 Department of Neurovirology, National Institute of Mental Health \& Neurosciences, Bangalore 560 029, India by a highly neurotropic RNA virus, taxonomically belonging to genus Lyssavirus, family Rhabdoviridae. Mammalian reservoirs for this exclusively neurotropic virus include Carnivora and Chiroptera, but transmission by rabid dogs still poses the greatest hazard worldwide. In India, dogs are the main vectors, accounting for $95 \%$ of the reported cases. In the USA, striped skunks, raccoons, foxes, and coyotes are the most important reservoirs perpetuating wildlife rabies; in Europe foxes and raccoons are the most important reservoirs; and in South Africa, dogs and mongooses are most important. Bat rabies, which is a significant threat in the USA and Europe, has not been reported in India to date. Human-tohuman transmission has been recorded through corneal, liver, and kidney transplants from donors with rabies misdiagnosed as Guillain Barré syndrome (GBS) or stroke [1-3].

Despite continued attempts at medical intervention, rabies remains an infectious diseases with the highest case fatality ratio [4]. The disease does not discriminate with regard to age, sex, geography, or occupation. According to World Health Organization (WHO) estimates, 50,000 human deaths are reported worldwide every year, with $60 \%$ of these cases being reported from India [5, 6]. Human rabies continues to be endemic in India, except for the islands of Andaman, Nicobar, and Lakshadweep [7].

The disease obtained the name "Rabies" owing to its dramatic and extraordinary clinical manifestations of violence or rage (the Latin rabere means "to rage or to rave", rabhas means "violence" in Sanskrit; and lyssa or lytta means "madness" in Greek).

The rabies viral infection produces 2 distinct wellrecognized clinical syndromes in humans: furious and paralytic rabies. The former, dominated by limbic symptoms, is the most recognized form of the disease, with prototypic symptoms of hydrophobia, aerophobia, and aggressive behavior. The paralytic form, however, presenting with ascending 
paralysis without "hydrophobic" symptoms, was initially recorded by Gamaleia in 1887 but was not widely recognized until several decades later [8-11]. The less common batrelated rabies has clinical features distinct from those of dogrelated rabies [4].

Efficacious rabies vaccines have been around for a long time and, combined with stray animal control measures, public health infrastructure, and good clinical evaluation of exposure, the risks posed by terrestrial animals can be minimized. However, effective treatment of the disease remains elusive, mostly because the precise mechanism of disease causation and death by the virus still remains uncertain. Most of our present knowledge is derived from studies on experimental animals, mostly rodents, infected with fixed (attenuated) laboratory strains of the rabies virus that have a different biology and does not truly reflect natural infection by the street virus (virulent) strains that causes infection in humans and animals [12-14]. The virus has a unique mode of entry, spread, and pathogenesis, completely different from all other viruses. It successfully evades immune system detection to reach the central nervous system (CNS) without a viremic phase, and this poses considerable limitations to both diagnosis (lack of antibodies/virus in circulating blood make it impossible to detect by serological/molecular biological tests) and treatment. Successful treatment requires novel strategies that can target the virus before entry into CNS or discover methods to target the virus within the CNS bypassing the blood-brain barrier (BBB). Herein, we review the available facts of rabies viral pathogenesis to determine steps at which intervention maybe possible. Evolving novel treatment strategies require an in-depth understanding of the biology of the virus, its modus operandi, and neuropathogenesis; for instance, inhibition of viral binding, transport and spread, and the targeting of the binding domains of the virus, which are highly conserved among different strains, can be potential targets for vaccine development and therapeutic strategies.

\section{Viral Transmission}

Rabies is an infection of domestic and wild animals that spreads to humans by 3 main modes: bites, mucous membranes exposure, and, less commonly, aerosol inhalation.

The virus is excreted in saliva and inoculation of virusladen saliva through the skin into muscle and subcutaneous tissues of the victim following bite of a rabid animal is the most common mode of infection. Most infections (90\%) are transmitted by bites of domestic animals like cats and dogs, owing to their close association with humans. The virus cannot cross intact skin. Scratches infected with saliva are a less common source of transmission, as the risk of infection is 50 times lower [4, 15]. Bat rabies virus is more infectious than dog rabies virus as it replicates more rapidly in non-neuronal cells and at lower temperatures. Percutaneous infection may occur during skin exposure following a minute bite that escapes attention. The exact mode of viral entry from dermal nerves into the CNS by the bat rabies virus is unclear [16].

Inhalation of aerosolized rabies virus was previously reported as an accidental event in a laboratory worker, who was infected while grinding rabid sheep brains for vaccine production [17], and by people in caves inhabited by numerous infected bats [18].

Human-to-human transmission is very rare and all recorded cases are iatrogenic following transplantation of tissues harvested from undiagnosed, rabies infected donors. Thus far, there have been 8 cases reported in corneal graft recipients $[19,20]$, and 3 reports from the USA and Germany of recipients of solid organs (kidneys, liver, lungs, corneas and an arterial segment) from organ donors who died of unrecognized rabies encephalitis [20-22].

Most patients died within 8 weeks of transplantation, with only a few survivors. Two recipients of corneal transplantation survived following explantation and replacement of corneal buttons, and pre- and postexposure prophylaxis [20]. One of the survivors with liver transplant had received vaccination $\sim 20$ years prior, while the Milwaukee regime facilitated survival for 7 weeks in another recipient [22]. Transmission via organ transplantation from a donor infected by raccoon rabies virus variant is on record. Three of the recipients received postexposure prophylaxis vaccination and remained asymptomatic, while one developed rabies, and succumbed 18 months following kidney transplantation [23]. No transmission from bite or nonbite exposures inflicted by infected humans has been recorded so far. Casual contact with a rabies-infected person, or contact with noninfectious fluid or tissue (urine, blood, feces) in healthcare workers and nurses does not constitute an exposure and does not require postexposure prophylaxis. The virus may be shed in breast milk, and there is one suspected case of transmission from a mother to a breastfed infant [24]. Transplacental infection, as occurs in animals, has not been reported in humans.

\section{Rabies Viral Entry and Incubation}

The incubation period (IP) is highly variable, ranging from 6 days to as long as 6 years akin to a slow virus disease [25, 26]. We reported a case of rabies from a south-Indian state; nearly 25 years after the dog bite occurred, and the victim manifested with hydrophobic rabies and eventually succumbed to it [27].The extreme variability in IP is attributed to host and viral factors, and hiding within safe sanctuaries in the host for prolonged incubation periods.

During the early IP, the virus remains sequestered at the site of inoculation entering an eclipse phase, undetectable with present-day techniques. The local replication time could determine the interval between exposure and manifestation of 
clinical signs [28]. Reverse transcription polymerase chain reaction (RT-PCR) and immunohistochemistry have shown viral replication in muscle cells, in skunks intramuscularly inoculated with wild-type virus [28]. Following local replication, the virus enters unmyelinated nerve endings at the neuromuscular junctions or the muscle spindles [29, 30]. Direct viral entry into the nerves without local replication results in very short IP, as occurs in cases with multiple bites in the head and neck region. Active or passive immunization probably act by restricting viral replication at site of entry and protect against spread of infection. An effective cell-mediated immunity is essential for successful elimination of the virus.

Receptors are important in viral entry, cell tropism, and spread. The most important receptors incriminated in rabies viral entry are the nicotinic acetylcholine receptors (nAChR) at the neuromuscular junction [31]. In vitro studies demonstrate 2 more putative receptors: neural cell adhesion molecule, expressed at the neuromuscular junction, and the p75 neurotrophin receptor [32-35], with a probable role in infection and viral spread [32].

Historically, the $\mathrm{nAChR}$ was the first-identified receptor for viral entry at the neuromuscular junctions. $\alpha$-Bungarotoxin, an antagonist of the nAChR, caused partial inhibition of infection in vitro in cultured chick myotubes and rat myotubes [31]. The localization of rabies viral antigen areas with rich cholinergic innervation, such as cerebral cortex and limbic structures, including amygdala, hippocampus, thalamus, hypothalamus, and basal ganglia, as seen in in vivo studies in experimental animals, confirms its cholinergic affinity. Variations in animal susceptibility is related to the distribution of $\mathrm{nAChR}$ in their muscles and other peripheral organs [36, 37]. For instance, foxes are highly sensitive, dogs less sensitive, and opossums highly resistant to rabies infection. $\mathrm{nAChR}$ antagonists appear to be logical targets for prevention of rabies viral entry and spread into brain.

$\mathrm{nAChR}$ are localized to neuromuscular junctions in the periphery, where they modulate skeletal muscle contraction. $\alpha$-Bungarotoxin is a competitive antagonist of $n A C h R s$, with high affinity and near irreversible binding. In the CNS, the major nicotinic receptor subtype that binds this toxin is the alpha7 subunit, a ligand-gated calcium channel found in anatomical regions of the brain essential for cognition, including cerebral cortex and hippocampus. The nAChR has been used therapeutically in a variety of conditions where localized inhibition of neuronal and/or muscle denervation is desirable, for example various dystonias, spasmodic torticollis, strabismus, blepharospasm, and other conditions with neuromuscular involvement, as also in the cosmetic treatment of facial wrinkles. Recombinant technology has helped develop modifications of the toxin with the same efficacy as its native form, but with varying receptor binding specificity, drug delivery routes, and long-term release preparations without side effects like paralysis, autonomic involvement, and so on. Whether it can be used in conjunction with passive immunization remains to be explored in humans. Knowledge of both the region of the virus involved in binding, and the binding domain on the receptor, may be helpful in developing new therapeutic strategies, especially for rabies virus that infects the CNS after successfully evade the host immune defenses.

However, the nAChR may not be solely responsible for viral spread in the CNS, as noncholinergic areas are also highly susceptible to rabies viral infection. Cellular sialic acid, galactose, mannose and $N$-acetylglucosamine, and gangliosides, but not fucose, are shown to be involved in the binding of rabies virus to the host cells [38-40]. Variability in the receptors involved in viral entry could influence the IP, by altering the neuronal groups involved, and this mechanism needs to be evaluated as alternate therapeutic targets.

\section{Viral Spread to the CNS}

Rabies virus propagates to the CNS from its site of inoculation via axonal transport in a retrograde fashion [41-43]. Travel to the CNS via the peripheral axons occurs at a fairly constant rate of 12 to $24 \mathrm{~mm}$ per day [44-46]. Fast axonal transport is mediated by microtubules, and slow axonal transport is actin mediated. Colchicine, a microtubule-disrupting agent, effectively inhibits fast axonal transport, preventing rabies viral spread in vitro [47]. Colchicine, which effectively functions as a "mitotic poison", has an anti-inflammatory property that is used in humans in treatment of gout, Behçet's disease, and relapsing polychondritis. In experimental rats, stereotaxic inoculation of colchicine into the striatum produced inhibition of intra-axonal transport of the rabies virus [48], but the inhibition was reversible. Use of osmotic pumps to enhance the duration of colchicine-mediated inhibition by delivering the drug continuously in the rat brain was also attempted [49]. Its use in human rabies has remained unexplored.

Although all available data support centripetal spread of rabies virus by axonal transport from the site of inoculation to the CNS, the mode of virus spread within the CNS appears to be more complex [50]. At present, 3 potential pathways are postulated: 1) virus dissemination within extracellular spaces; 2) intraaxonal transport via fast axonal transport; and 3) cellto-cell transmission between contiguous cells and their processes. Determining the exact mode of spread may help design new therapeutic targets, such as monoclonal antibodies, that inhibit viral spread within the CNS.

Wide dissemination in extracellular spaces is an efficient and rapid mechanism of virus dissemination within the CNS but is more important in rapid progression of fixed strain of the rabies virus [51].

Transit via the axonal route is important in the progression of the disease by street virus [43], allowing it to effectively circumvent the host immune responses. The importance of long 
ascending and descending tracts as a route of virus spread within the CNS, as described in skunks [52], was observed in human and canine studies from our center (unpublished data). Interruption of axoplasmic flow by alkaloid drugs such as colchicine and vinblastine have succeeded in preventing the ascent from the site of inoculation to CNS [47, 53, 54]. Interestingly, in vivo studies by intracortical inoculations of rabies virus into primates, demonstrated that transneuronal transfer is strictly unidirectional, proceeding in a retrograde direction $[55,56]$.

Directional transport of various proteins into axons or dendrites is governed by molecular motors. Anterograde transport is mediated by the kinesin superfamily, whereas retrograde transport is dependent on dyneins [57]. Retrograde dyneinmediated axonal transport of rabies virus enables its spread over long distances in the CNS. Though active rabies virus transport is widely believed to be unidirectional, visualization by live microscopy in infected dorsal root ganglia neurons revealed fast anterograde axonal transport of rabies virus via kinesin-dependent transport machineries [58].

Cell-to-cell transmission of virus between contiguous cells and their processes, particularly at synaptic junctions, is operative in experimental animals (Fig. 1A, B), and less frequent in human rabies $[29,59,60]$.

The virus replicates in the dorsal root ganglion and trigeminal ganglion (sensory neuron) and anterior horn cells (motor neurons) of spinal cord [61]. Anterograde transport in dorsal root ganglia is dependent on virus glycoprotein G. Mutant rabies virus lacking glycoproteins fails to move anterogradely within the axon. The complete enveloped virus particles or cotransport of virus ribonucleoprotein and G-containing vesicles occurred from dorsal root ganglion neurons [58].

As the rabies virus receptors are detected only on motor endplates and motor axons, uptake and transmission to the
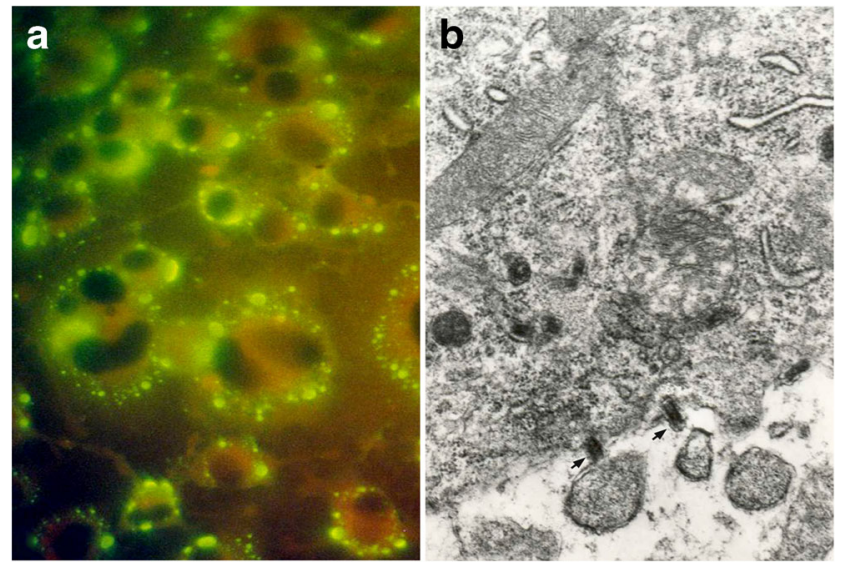

Fig. 1 (A_Cell line (Neu2A) infected with CVS strain of rabies virus demonstrates fluorescent rabies viral antigen aggregated along the cell membrane representing budding from the cell surface (immunoflurescence $\times 400)$. (B) Electron micrograph $(\times 36,000)$ shows viral particles budding along the cell membrane (arrows) into the extracellular space of a brain stem neuron in a mouse inoculated with the CVS strain of rabies virus
CNS is believed to occur exclusively through motor axons [62]. Involvement of sensory and autonomic ganglia occurs by centrifugal propagation from the CNS to the periphery. Virus is therefore detectable from the end organs only in terminal stages of the disease $[63,64]$. Valuable insights into the viral pathogenesis of rabies come from transneuronal tracing studies in primates and rodent models prior to the development of clinical disease. These studies have shown that rabies virus propagation occurs at chemical synapses and not via gap junctions or cell-to-cell spread. Infected neurons remain viable, both morphologically and functionally as they continue to express neurotransmitters. Retrograde transmission causes all neuronal groups of the same synaptic order to be infected simultaneously, irrespective of their neurotransmitter class, strength of synaptic connections, or distance from entry [62].

Components of the rabies virus modulate its neuroinvasiveness and neurovirulence. The rabies virus glycoprotein has been shown to play a key role in several steps of rabies pathogenesis - viral uptake from site of inoculation, axonal transport, and trans-synaptic spread in CNS, as well as the viral distribution in the nervous system [65-67]. The rabies viral glycoprotein $(\mathrm{G})$ is critical for both neutralizing antibody production and the initiation of cell-mediated immune response. Differences in $\mathrm{G}$ protein affect $\mathrm{G}$ protein receptor interactions with $\mathrm{nAChR}$ at the periphery, P75 neurotrophin receptor, and antiglycolipid or ganglioside in the CNS. Minor variations in $\mathrm{G}$ protein such as substitution of arginine at position 333 affects neuroinvasiveness by use of different neuronal pathways [68]. Interaction between the phosphoprotein of rabies virus, and LC8 - the cytoplasmic dynein light chain that regulates microtubule-mediated transport-is implicated in viral transport [69-71]. However, mutant viruses with deletion in phosphoprotein encompassing LC8-interacting motif retained their neuroivasiveness and virulence [72]. Neuroattenuation required simultaneous substitution of arginine at position 333 of viral glycoprotein with deletion of LC8, reinforcing that rabies viral glycoprotein plays a more important role than phosphoprotein [72]. Several viruses such as HIV, poliovirus, herpes simplex virus, African swine flu, and adenovirus use dynein for intracellular transport of the virus prior to viral replication in the perinuclear area in the microtubule organizing center, where the new virions are assembled. Small peptide inhibitors that disrupt this high-affinity binding domain between dynein and viral protein were shown to interfere with African swine fever viral replication, suggesting a possible novel therapeutic approach for rabies infection also [73].

Interaction of rabies virus phosphoprotein with microtubules is identified as a unique mode of viral antagonism of interferon (IFN) responses disabling the IFN-signaling pathway that is vital to the innate antiviral host immune response. This unique mechanism of rabies viral subversion of IFN signaling is critical to its pathogenicity, and also suggests novel 
targets for the development of antiviral drugs or attenuated viruses for vaccine applications [74].

The rabies viruses have evolved mechanisms to hijack their host cell's transportation system for movement within cell cytoplasm to reach paranuclear zones for viral replication and subsequent movement towards the plasma membrane for egress from the cell surface. Microtubule-destabilizing agents such as nocodazole, vinblastine, and taxol have shown antiviral effects in in vitro studies, but are highly toxic [75].

Detailed insights into the various steps involved in viral replication and infection, including cytoplasmic transport, may open up new avenues for antiviral drug development, primarily directed against viral, and other cellular targets, such as kinases, microtubules, and so on, and identify antiviral targets for vaccine development. Once clinical symptoms of rabies encephalitis sets in, no therapy has proven effective.

\section{Clinical Features}

Clinically, the disease presents in 2 distinct forms-furious (encephalitic) or paralytic (dumb) rabies; two-thirds of patients develop the furious form $[25,76]$.

\section{Furious Rabies}

Furious rabies is characterized by periods of agitation and confusion alternating with period of lucidity, and signs of autonomic dysfunction like lacrimation, pupillary dilatation, hypersalivation, and excessive sweating. The pathognomonic symptom of hydrophobia (fear of swallowing) comprises a triad of inspiratory muscle spasm, painful laryngospasm, and fear. It is initially triggered by attempts to drink water, but eventually the reflex can be provoked by draft of air (aerophobia) or even the mention of water. Phobic spasms in response to tactile, auditory, visual, or olfactory stimuli indicate brain stem involvement. Approximately one-third of patients die within days of developing hydrophobic spasms. Most rarely survive $>1$ week, without intensive ventilatory support.

\section{Paralytic Rabies}

Paresthesia and weakness mark the onset of the paralytic form in the bitten extremity, progressively involving all the limbs, and pharyngeal and respiratory muscles. This form of rabies causes a diagnostic dilemma as aerophobia and hydrophobia manifest in only half the cases, before the stage of coma. Furthermore, early in the course of the disease, flaccid paralysis of all the limbs and areflexia closely resemble GBS, with relative sparing of consciousness. This problem is further compounded in the absence of a history of dog bite. The clinical course is generally prolonged to weeks and paralytic features predominate. The pathogenesis responsible for the 2 differing clinical forms of rabies has always been a subject of intense interest.

\section{Bat Rabies}

Patients with bat-related rabies have nonclassical signs- - neuropathic pain, radicular pain, sensory motor deficits, and, in the prodromal phase, choreiform movements of the bitten limb. Brainstem signs and myoclonus occurs commonly with hemiparesis or hemisensory loss, ataxia, and convulsive and nonconvulsive seizures; hallucinations are frequent.

Clinical signs and symptomatology of the paralytic and encephalitic forms of rabies suggest involvement of spinal cord and peripheral nervous system in the former, and cerebral cortex and limbic system in the latter. However, no significant differences in regional distribution of rabies virus antigen or inflammatory changes between the furious and paralytic forms have been demonstrated in autopsy studies [68]. Antemortem magnetic resonance imaging has also shown a predilection for brain stem, hippocampus, and hypothalamus involvement in both the clinical forms of rabies [77].

Differences in immune response between both forms of rabies have been suggested. In the encephalitic form, heightened immune response has been found with T-cell infiltrates, high serum concentrations of the interleukin (IL)-2 receptor and IL-6, and early mortality [78, 79]. In contrast, patients with paralytic rabies have been reported to have defective immune responsiveness, lack of lymphocyte proliferative responses to rabies viral antigen, and lower levels of the serum cytokines, IL-6 and soluble IL-2 receptor [79-81]. Pathological studies demonstrate peripheral nerve inflammation and demyelination as the prime pathological manifestation in cases of paralytic rabies and chromatolysis in anterior horn cells in encephalitic form [11, 78, 82].

No viral genotypic differences were found between the 2 forms of clinical rabies by Hemachuda et al. [83], who analyzed the entire glycoprotein $(\mathrm{G})$, nucleoprotein $(\mathrm{N})$ and phosphoprotein $(\mathrm{P})$ genes of rabies viruses from cases of paralytic and encephalitic rabies. The differences found in $G$ and $P$ proteins were outside the ectodomain and not in the interactive or immunodominant region of $\mathrm{G}$ protein responsible for virus invasion.

Distinguishing paralytic rabies from GBS is a frequent clinical dilemma. In a study carried out at our center, fever at onset, paresthesias, muscular fasciculations, flaccid weakness confined to the bitten extremity, rapid deterioration with encephalon and autonomic involvement, cerebrospinal fluid (CSF) pleocytosis with demyelination, and axonal degeneration on electrophysiological studies were the cardinal features in cases of paralytic rabies, in contrast to conduction blocks in nerve conduction studies of GBS [84]. Variable lymphocytic 
infiltration, microglial nodules, and neuronophagia can be observed in the spinal cord in both GBS and paralytic rabies. Immunophenotypic studies revealed a predominance of $\mathrm{CD} 8^{+}$ $\mathrm{T}$ cells in GBS, in contrast to macrophage-rich infiltrates in paralytic rabies, correlating with high CSF IFN- $\gamma$ and IL-6, and low tumor necrosis factor (TNF)- $\alpha$ and IL-4 [85]. The striking similarity in clinical, as well as pathological, changes between the paralytic form of rabies and GBS raised the possibility that the same immunopathogenetic mechanism implicated in GBS associated with Campylobacter jejuni, Mycoplasma pneumonia, cytomegalovirus, and Epstein-Barr virus could also be operative in paralytic rabies, with the development of autoantibodies to peripheral myelin due to molecular mimicry [86]. In fact, one of the initial historical cases of the acute motor sensory variant of GBS was found, on review, to be a case of paralytic rabies [87]. Participation of autoantibodies against peripheral nerve antigens in the evolution of paralysis is also suggested by vivid enhancement of ventral and dorsal nerve roots on magnetic resonance imaging, similar to GBS [77, 88]. However, neither neutralizing antibodies nor antiganglioside nor myelin basic protein antibodies have been consistently demonstrated in CSF in paralytic rabies [78, 81, 89].

The biological basis for the characteristic aggressive behavior in the encephalitic form of rabies remains unclear. In an analysis of 42 autopsied cases of rabies at our center, 5 subjects had behavioral abnormalities, including aggression, and were admitted to psychiatric services with diagnoses of manic psychosis [90]. The aggressive behavior observed in natural hosts like human and canines has not been observed in experimental animals inoculated with a laboratory-attenuated fixed strain of the virus [91]. Madhusudana [92] reported a case of rabies presenting with hypersexuality, reflecting the probable involvement of amygdala, hypothalamus, and cingulate gyrus. The basic physiology of aggressive behavior in mammals correlates with finding of rabies viral antigen in raphe nuclei, red nucleus, and substantia nigra, implicating aberrant serotonin neural transmission [93]. The aggressive behavior in canines with furious rabies is a natural strategy for horizontal transmission of the virus and maintains survival of the virus in the canine population.

Although the clinical symptomatology is dramatic, at autopsy, the findings that typify most viral encephalitis (inflammation and neuronophagia) are surprisingly minimal and the infected neurons do not show morphologic signs of degeneration (Fig. 2A-C) [94, 95]. Several hypotheses have been proposed to explain this strange dichotomy. Fu et al. [96] proposed that neuronal dysfunction rather than morphological changes plays a role. Others have demonstrated dysfunction of ion channels in infected cell culture [97], and defective cholinergic neurotransmission [98]. Induction of inducible nitric oxide synthase mRNA and increased levels of nitric oxide have been demonstrated in rodents inoculated with the virus

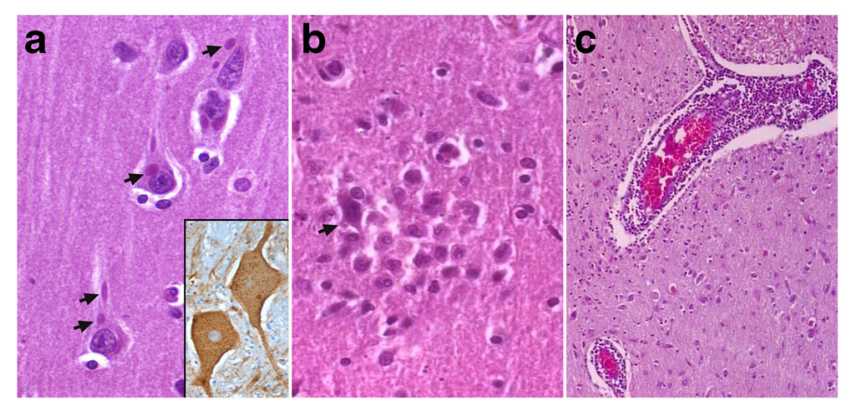

Fig. 2 Neuropathological changes in rabies viral encephalitis. (A) Pyramidal neurons of cerebral cortex show multiple characteristic eosinophilic intracytoplasmic Negri bodies (arrows). Note the wellpreserved neuronal morphology of infected neurons without evidence of neuronal degeneration and prominent nucleoli. (Inset) Rabies viral nucleocapsid antigen seen as fine, stippled deposits and occasional larger aggregates within the cytoplasm within the magnocellular neurons of the brain stem reticular formation (hematoxylin and $\operatorname{eosin} \times 240$; inset: immunoperoxidase for rabies viral antigen $\times 320$ ). (B) Microglial nodules surrounding a degenerating neuron (arrow). Note absence of Negri bodies within the degenerating neuron (hematoxylin and eosin $\times 280$ ). (C) Perivascular lymphocytic cuffing around the parenchymal vessels in the brain stem in a case of rabies encephalitis (hematoxylin and eosin $\times 120$ )

$[96,97,99,100]$. The role of these in natural rabies infection in humans is uncertain.

Similar to other viral diseases, early reports suggested that apoptosis played an important role in causing cell death in animals inoculated with a laboratory-adapted CVS strain of rabies virus [101-103] Apoptosis was found only in suckling mice when intracerebrally inoculated with rabies virus (CVS strain), and correlated with viral load and severity of clinical symptoms progressing to death, but apoptosis was absent in adult mice and in peripherally inoculated animals [104-108]. More neurovirulent strains produced less apoptosis and vice versa [107, 109]. Ubol and Kassisith [110] reported massive apoptosis in the brains of Swiss albino mice inoculated with the bat strain of rabies virus [110]. However Yan et al. found minimal apoptosis in mice inoculated with silver-haired bat rabies virus [111].

In human rabies, however, studies have conclusively shown that neuronal apoptosis is absent and has no role in natural infection with the wild-type viral strain of rabies $[112,113]$. On the contrary, using dUTP nick end labeling, we found that many of the inflammatory cells showed apoptotic cell death, which suggests that apoptosis in human rabies is protective rather than pathogenic, and serves as an efficient evasive mechanism of depleting host inflammatory cells, to ensure the survival and propagation of the virus in the infected neurons [113].

In a recent study, transgenic mice expressing yellow fluorescent protein inoculated with fixed strain of rabies virus revealed prominent neuronal vacuolation of the cell soma, dendrites, and presynaptic endings in cerebral cortical and hippocampal neurons, suggesting mitochondrial damage and 
organelle failure [114]. Kammouni et al. [115], using a proteomics approach, demonstrated that the phosphoprotein of rabies virus in in vitro mouse neuroblastoma cell lines causes mitochondrial dysfunction by complexing with the complex I subunit of mitochondria, thereby inducing oxidative stress via induction of reactive oxygen species.

\section{Diagnosis}

Early diagnosis of rabies is essential for initiation of specific therapy if an aggressive approach is considered and for the prevention of the exposure of healthcare workers to the virus.

The lack of sensitive tests for antemortem diagnosis has been a limiting factor but reflects the peculiar pathogenesis of the virus lacking a viremic phase and evading exposure to the systemic immune responses. This makes routine serological tests used for diagnosis of other viral infections of little use in rabies diagnosis. The test results are highly influenced by intermittent virus shedding, the timing of sample collection in relation to disease onset, the type of specimens collected, and, importantly, the type of rabies (negative test results are especially seen in paralytic form of rabies, compounding the diagnostic dilemma). Ensuring cold chain and refrigeration of fluids and tissue samples during storage and transport and rapid processing should be carried out to preserve RNA for tests employing RT-PCR assays.

A recent study demonstrated $100 \%$ specificity in RT heminested PCR targeting the $\mathrm{L}$ polymerase gene in antemortem human rabies diagnosis [116]. The study demonstrated higher sensitivity of detection from skin biopsies $(98.3 \%)$ than from saliva (70.2\%), irrespective of the time of collection (from day 1 of illness to postmortem), but when 3 daily serial samples of saliva were tested, the sensitivity reached $100 \%$.

Table 1 summarizes the information available from studies of diagnostic tests and their sensitivity and specificity in diagnosis [116-120].

\section{Serologic Tests}

Serological tests detect rabies viral antibodies in only $20 \%$ of unvaccinated patients with rabies 1 to 26 days after the onset of the disease. The Centers for Disease Control recommends that if no vaccine or rabies immune serum has been given, the presence of high-titre antibody to rabies virus in the serum is diagnostic and tests on CSF may not be necessary. However, antibody to rabies virus in the CSF, regardless of the immunization history, suggests a rabies virus infection [119]. Laboratory tests for antibody include indirect immunofluorescence and virus neutralization. Rabies viral antibodies usually appear after 7 days of the illness and may be a good diagnostic marker in patients with paralytic rabies, who usually survive longer. Antibodies appear in the CSF later in the disease course $[117,121]$.

\section{Skin Biopsy}

Skin biopsy samples should be taken from the nuchal area containing hair follicles with peripheral nerves. The recommended sampling area is the upper portion of the nape of the neck, an easily accessible area with a high density of hair. Viral nucleocapsids are located in the nerve endings around the hair follicles. Testing methods available include fluorescent antibody testing (FAT) on frozen sections but is the least sensitive. The Centers for Disease Control recommends examination of at least 20 sections on 5 to 6-mm full-thickness skin biopsies to detect rabies nucleocapsid inclusions around the hair follicles, if FAT testing is used for enhanced sensitivity of up to $86 \%[119,122]$. The timing of biopsy influences the result, with $82 \%$ sensitivity in first 4 days after onset of the disease, which drops to $60 \%$ between 5 and 8 days after infection. RT-PCR assays have a much higher sensitivity, but PCR directed against the $\mathrm{N}$ gene has a lower sensitivity (70 \%) [123] versus a very high sensitivity of $>98 \%$ using RT hemi-nested PCR targeting the L polymerase gene [116].

\section{Corneal Smears}

Corneal imprint using the FAT for detection of rabies viral antigen has a low sensitivity of upto $42 \%$ and specificity of $100 \%$, but is dependent on optimum tissue preservation [124].

\section{Body Fluids}

Laboratory tests of secretions and biological fluids such as saliva, spinal fluid, tears, and tissues may be used to diagnose rabies. A positive result is indicative of rabies, but a negative result does not rule out the possibility of infection [120].

The highest virus yield was noted with specimens collected within 3 days of onset and tested by RT-PCR for the N gene. Saliva samples had the highest rate of positivity, followed by CSF and urine samples. While the sensitivity of all specimens dropped after day 3, saliva remained the most reliable source for virus detection (from days 4 to 9 ) and sensitivity of urine and CSF during days 4 to 6 was almost the same. Test results of saliva specimens, CSF, and urine obtained during days 10 to 12 were all negative [117].

\section{Saliva}

Saliva specimens are used to detect rabies virus using viral isolation or, more commonly, to detect viral RNA using RTPCR. The timing of saliva sample collection greatly influences the yield of molecular diagnosis. Virus detection is highest during the first 2 to 3 days after the onset of symptoms 
and remains stable from day 2 to day 7 , or even later [116, 125]. Intermittent shedding of the virus in saliva influences the diagnostic yield. The collection of 3 serial daily saliva samples enhanced the sensitivity to $100 \%$ [116]. The difference in sensitivities between saliva swab samples $(52.9 \%$; 17 samples) and liquid saliva samples (74.6\%; 67 samples) was not found to be statistically significant.

\section{Brain Biopsy}

Brain biopsy is the gold standard for diagnosis, but is not recommended for antemortem diagnosis, as its impractical [117]. The site and timing of biopsy is important, as falsenegative results may occur when biopsy of the frontal and temporal regions is carried out on the first day of the disease when antigen localization will be mostly in brain stem and cerebellum.

The use of molecular diagnostic tests, RT-PCR and nucleic acid sequence-based amplification techniques in antemortem human rabies diagnosis, has helped overcome the low sensitivity of viral antigen detection methods. They have the highest level of sensitivity but can produce false-positive or false-negative results and therefore must be interpreted with caution. Molecular genetic studies have assisted in epidemiological studies by genotyping the lyssavirus and is of importance in vaccine development. The development of several improved diagnostic assays for rabies viral antigen [and antibody detection (sandwich enzyme-linked immunosorbent assay) and highly sensitive assays for viral nucleic acid detection (RT-PCR and real-time PCR] on clinical samples has revolutionized rabies diagnosis. The available techniques for human rabies diagnosis have been reviewed in a recent publication [126]. In a study from our center, Mani et al. [127] reported sensitivities of $45.4 \%, 60.0 \%$, and $85.7 \%$ in CSF, nuchal skin biopsy, and saliva samples, respectively, obtained for antemortem rabies diagnosis by real-time PCR. In a recently published audit from a rabies diagnostic laboratory in India, despite several challenges in obtaining multiple/serial clinical samples and their transport to the laboratory, antemortem confirmation of rabies could be achieved in $40.6 \%$ of the 128 clinically suspected cases by a combination of laboratory diagnostic assays (detection of viral RNA in CSF, skin, and saliva, and neutralizing antibodies in CSF) [128].

As an inverse correlation has been reported between the presence of viral RNA and detection of rabies virus neutralizing antibodies in CSF, whenever feasible, a combination of these methods should be used. Detection of viral RNA by PCR-based techniques on multiple clinical samples such as saliva, nuchal skin biopsy, and CSF, and serial sampling (for both antibody and viral RNA detection) is recommended to enhance the sensitivity of antemortem diagnosis $[127,128]$. Antibody testing is also an effective way to monitor the immune response within the CNS and predict a possible clearance of the rabies virus in patients initiated on any experimental therapy [161]. Despite significant advances in antemortem diagnostic techniques, a negative result using multiple tests on several clinical samples obtained antemortem cannot categorically exclude a diagnosis of rabies. Detection of rabies antigen in brain tissue (obtained postmortem) by the FAT technique remains the gold standard with which to establish unequivocally a diagnosis of rabies.

\section{Postmortem Diagnosis}

The gold-standard diagnostic technique recommended by WHO is the demonstration of virus antigen in brain tissue by direct fluorescence assay, which has $100 \%$ sensitivity [120]. Rabies tissue culture infection test and mouse inoculation test are confirmatory tests for direct fluorescence assay, but are time consuming and labor intensive.

Brain biopsies is the preferred sampling for postmortem diagnosis in humans and animals. A brain biopsy specimen can be obtained via the orbital, or transnasal route using TruCut biopsy needles [129-131], or via the occipital route through foramen magnum with use of lumbar puncture needles [132]. The transnasal/orbital route will contain fragments of orbitofrontal cortex. The transforamen magnum route will obtain samples from cerebellum and brain stem. The tissues should be refrigerated until FAT and molecular diagnostics, and tissue in $50 \%$ glycerol saline is needed for viral isolation. Dried smears of brain tissue can be kept on filter papers when safe transportation of the infected material is not possible, or samples can be submitted in $10 \%$ formalin for antigen detection by immunohistochemistry.

Antigen detection by FAT is both a rapid and sensitive method with which to diagnose rabies infection in animals and humans and is currently the gold standard for rabies diagnosis. However, FAT can provide false-negative results, owing to variability in antigen localization, as well as when bat specimens are tested. Virus isolation can be used for confirmation of FAT. Detection of Negri bodies in fixed tissues is highly variable (10-65\%) and requires extensive sampling, which is laborious and time consuming. Antigen detection can also be performed by immunohistochemistry or the newly developed direct and indirect rapid immunohistochemical test (Centers for Disease Control, Atlanta, GA, USA) [133], but both tests require optimum preservation of morphology. The sensitivity of detection is determined by distribution of antigen within brain regions, which is highly variable. Binghem et al. [134], in an elegant study, showed that sampling from thalamus, pons, and medulla is the most reliable, as samples were invariably positive in all cases. The cerebellum, hippocampus, and other parts of brain were negative in $4.5 \%, 4.9 \%$, and 3.9 to $11.1 \%$ of samples, respectively. The highest prevalence of antigen was seen in thalamus (97.8 \%) [134]. 
Quantitative proteomic analysis of human brain tissues obtained at autopsy from confirmed cases of encephalitic and paralytic rabies identified signature proteins differentially regulated using high-resolution mass spectrometry. Certain proteins like Karyopherin alpha 4 and calcium calmodulindependent kinase 2 alpha were overexpressed only in paralytic rabies, and glutamate ammonia ligase was overexpressed in both paralytic and encephalitic rabies. These molecules need to be further validated in biological samples such as CSF/ saliva in order to ascertain their potential use as antemortem biomarkers for diagnosis of rabies [135]. Metabolomic study of CSF from humans treated for rabies with proton nuclear magnetic resonance $\left({ }^{1} \mathrm{HNMR}\right)$ spectroscopy identified metabolites that differentiated rabies survivors from those who subsequently died [136]. Further studies may provide new insights into the diagnostic and prognostic significance of these tests and mechanisms of rabies pathogenesis that may open up newer therapeutic avenues.

\section{Treatment}

The aim of treatment is to prevent the development of rabies. The most critical steps include thorough wound cleaning and the use of postexposure prophylaxis with hyperimmune serum and active immunization, based on the category of bite [137]. These measures together reduce the mortality risk from 37 to $60 \%$ to almost zero following a bite from a rabid animal [138].

\section{Postexposure Prophylaxis}

The main aim of postexposure prophylaxis is to neutralize the inoculated virus before it gains entry into the nervous system. The window of opportunity available is only up to $2 \mathrm{~h}$ following the bite. Postexposure prophylaxis includes wound care, passive immunization with immunoglobulin, and active vaccination.

\section{Local Wound Treatment}

Wound care is the most critical step in the prevention of infection. In experimental animals, it has been demonstrated that wound cleaning within the first $3 \mathrm{~h}$ of exposure to rabies almost completely prevented transmission of the virus [138]. The rabies virus is susceptible to killing by soap and drying. Hence, thorough wound cleaning with water and soap, iodine, 40 to $70 \%$ alcohol, or quaternary ammonium compounds (cetrimide), is effective in neutralizing the virus. Suturing of the wound must be avoided.

\section{Passive Immunization}

The rationale of passive immunization is to provide rabiesspecific antibodies that neutralize the virus locally and systemically within the first week, as response to active immunization takes 2 weeks to take effect. It is available in 2 forms: human rabies immunoglobulin (HRIG) and equine rabies immunoglobulin (ERIG). This is especially important in those at severe risk of infection (e.g., category III bites, and multiple head and neck wounds). Immunoglobulins cannot cross an intact BBB; hence, they are ineffective once the virus enters the CNS.

The immunoglobulin (HRIG dose $20 \mathrm{IU} / \mathrm{kg}$ body weight; ERIG dose $40 \mathrm{IU} / \mathrm{kg}$ body weight) is infiltrated locally around the wound site, and the remainder injected intramuscularly, far from the vaccination site. Technically, immunoglobulin should be given in all previously unvaccinated cases. Hypersensitivity reactions can occur in between $1 \%$ and $6 \%$ of individuals [139]. HRIG is very expensive and not freely available in the developing countries that have the highest prevalence of rabies. ERIG is available but caries risk of allergic reactions.

Once the symptoms of rabies set in, however, death is inevitable. The mainstay of treatment is intensive care support via induction of paralysis, sedation, and ventilation, and administration of narcotic analgesics, antiepileptic medications, and neuromuscular blockers to abrogate the neurological manifestations. Adequate care to prevent exposure of healthcare workers or family members to the virus using barrier nursing is essential; transmission of rabies virus from patients to healthcare workers has, to date, not been documented [140].

\section{"Milwaukee Protocol"}

In 2004, Willoughby et al. [141] reported the survival of a teenager who developed rabies following exposure to a rabid bat in USA. The case was unique as she was the first reported human survivor of rabies who had not received rabies prophylaxis prior to onset of illness and had an almost complete recovery following experimental therapy, which is now known as the "Milwaukee protocol", coupled with extensive physical and neurological rehabilitation. She was treated with an intense antiexcitotoxic strategy while the native immune response matured. A therapeutic coma was induced using a $\gamma$ aminobutyric acid receptor agonist with benzodiazepines and barbiturates, along with $\mathrm{N}$-methyl-D-aspartate receptor antagonism with ketamine and amantadine, to reduce excitotoxicity, brain metabolism, and autonomic reactivity.

However, despite the initial optimism and a few more success stories, several attempts to replicate this have been unsuccessful, leading to skepticism and reservations regarding its scientific rationale for routine use [142-147]. Nevertheless, increasing reports of survival/prolonged survival from rabies 
in the recent past, including those from India, albeit with neurological complications, should provide an impetus to the scientific community to explore newer therapeutic strategies to counter this fatal disease.

\section{Indications for Institution of Aggressive Therapy}

Wherever excellent critical care resources are available, an aggressive management approach can be considered on a case-by-case basis. Young, healthy, and immunocompetent individuals; patients who have received rabies vaccination prior to onset of illness; those who develop rabies due to a bat variant; early appearance of rabies-neutralizing antibodies in CSF and serum; and mild neurological illness at the initiation of therapy are regarded as favorable circumstances in which to attempt aggressive therapy [147].

In the early stage of the illness, when results of diagnostic tests for rabies may not yet be positive or unavailable, treatment initiation should not be delayed if there is strong clinical evidence in support of a diagnosis of rabies [137].

\section{Pharmacological Bases for Aggressive Therapy}

Currently aggressive therapy combines the use of antiexcitatory (ketamine) and antiviral drugs (ribavirin, amantadine,) and intensive care, while immune response is enhanced by immunization (active and passive immunization, monoclonal antibodies).

\section{Immunization}

Intradermal active immunization with rabies vaccine at multiple sites is used to accelerate antibody response (the intramuscular route takes at least 1 week to produce immunity).

Passive immunization using rabies immunoglobulin (HRIG or ERIG) and monoclonal neutralizing antibodies are employed to achieve viral clearance. Rabies immunoglobulin cannot cross the CNS and can only assist in viral neutralization prior to entry into CNS. Monoclonal rabies viral antibodies (intravenous and intrathecal route) can cross the BBB and, in rat models, immunoglobulins have shown ability to inhibit cell-to-cell spread of virus within the CNS and restrict rabies virus RNA transcription. Postexposure treatment of rats with a monoclonal antibodies successfully resulted in viral clearance from the CNS and protected animals against a lethal rabies virus infection [148].

Ketamine is an anesthetic agent that is considered a potential therapeutic agent in the management of human rabies on account of its inhibitory effect on RNA transcription and $\mathrm{N}$ methyl D-aspartate receptor antagonistic function that might limit viral spreading in tissue $[140,149]$. Its ability to rapidly cross the BBB is of potential advantage in reaching the rabies virus within the CNS. Benzodiazepines and barbiturates $(\gamma$ - aminobutyric acid receptor agonists) have been used for induction of therapeutic coma and to reduce the brain excitatory metabolism and autonomic reactivity.

Amantadine and ribavirin have demonstrated antiviral activity [150]. In vitro studies have demonstrated its efficacy [151], but this has not been seen in in vivo studies, owing to its limited capacity to cross the BBB [152]. Intrathecal or intraventricular administration with Ommaya reservoir might be of benefit, but a trial in a single human rabies case, using the intrathecal and intravenous routes, failed, in combination with IFN- $\alpha$ [153].

Corticosteroids are not recommended for use as in mouse models as the use of corticosteroids increased the mortality rate and shortened the incubation period [154]. Lack of inflammatory response, despite widespread antigen distribution in the brain, makes cerebral edema a rare complication in rabies. Hence, corticosteroids are used only for treatment of adrenocortical insufficiency and are not recommended for rabies therapy. It is also believed that corticosteroids may close the BBB and thereby reduce the passage of therapeutic agents through it [155].

Currently, there is no specific, effective treatment for human rabies. A combination of therapies, as mentioned above, has been used, but none has demonstrated significantly promising results in various clinical trials. In addition to the quest for new, efficacious antiviral agents, novel approaches for treating human rabies should include "neuroprotective" agents, induced generalized or localized therapeutic hypothermia, and a combination of various therapeutic approaches [147].

\section{Survival Following Rabies Encephalitis}

Mortality after untreated bites by rabid dogs ranges from $38 \%$ to $57 \%$ and depends on the severity and location of the wound, as well as on the presumed virus concentration in the saliva $[16,156]$.

Although believed to be $100 \%$ fatal, approximately 15 human survivors have been recorded [141, 157-161]. The first 12 reported cases have been reviewed in detail by De Souza and Madhusudana [162], including 2 cases from India [161]. Recently, 3 more cases of survival from human rabies have been reported from India [163-165]. All 12, except three, had received complete or partial postexposure prophylaxis prior to the onset of clinical symptoms. A hyperactive immune response with very high levels of antibodies in serum and CSF was documented in all the survivors (including those who did not receive postexposure prophylaxis). Two of the cases received rabies immunoglobulins, and the rabies virus was not isolated nor antigen demonstrated. One of the cases demonstrated classical signs of rabies. Only one case with complete neurologic recovery was documented [158], while all others had partial recovery with disabling neurological 
complications. The robust immune response causing clearance of rabies virus from the periphery or infection by less virulent isotype has been debated.

Medical management has been shown to prolong survival for up to 133 days $[166,167]$. Autopsy study of cases with prolonged survival of up to 14 days after intensive care with ventilation, IFN therapy, and ribavirin demonstrated widespread Negri bodies with minimal inflammation [168].

Factors influencing prolonged survival is unclear. In vitro studies in experimental animals found survival correlated with low IL-6 levels [169]. Inhibition of inducible nitric oxide synthase prolonged survival via its effect on viral replication and apoptotic cell death [170]. Reports also suggest that modulation of TNF- $\alpha$ and upregulation of IFN- $\gamma$ would be a powerful antivirus strategy in cases of viral encephalitis, as cytokine signaling via the $\mathrm{p} 55 \mathrm{Kd} \mathrm{TNF}-\alpha$ receptor is deleterious for the survival of the host [171].

\section{Prophylaxis}

\section{Pre-exposure Prophylaxis}

To date, no human live attenuated or recombinant rabies vaccine has been licensed for use in humans. All human rabies vaccines in use are inactivated and do not elicit a cytotoxic Tcell response important for virus clearance [172]. Several types of vaccines are in use, and are compared with human diploid cell rabies vaccine (considered the gold standard for cell culture vaccines), and include Vero cell vaccine (produced in monkey kidney cells) and Rabipur vaccine (chick cell line). These have greater effectiveness and lower adverse reactions than the neural tissue-derived Semple vaccine. There is no contraindication for the vaccine and can be administered to pregnant women, children, and those on any medication. Neurological reactions associated with cell culture vaccine are extremely rare; documented in approximately 1 in 500, 000 patients. Only 6 cases (prior to 1996) of neurological reactions such as weakness or paresthesias and permanent deficit of the deltoid muscle have been recorded. One patient developed a disease similar to multiple sclerosis.

Pre-exposure vaccination is recommended to those who are at the risk of exposure to rabies such as dog-handlers, veterinarians, laboratory workers, children living in high-endemic countries playing with street dogs, and travelers to such countries for periods exceeding 1 month $[137,173]$.

Three doses of tissue culture vaccine is administered in the deltoid on days 0,3 , and 28 . The estimated seroconversion rate is $98.2 \%$ [174]. It is not deemed essential to check antibody levels except in those at high risk of infection (e.g., exposed laboratory staff). Booster doses at between 6 and 24 months is recommended for those at high risk, to prolong protection [137].

\section{Post-Exposure Prophylaxis}

Various scientifically approved regimens for postexposure prophylaxis are used worldwide. Protocol varies depending on previous vaccination status. In unvaccinated individuals, 5 doses are to be given on days $0,3,7,14$, and 28 . Previously vaccinated individuals, if re-exposed, should receive 2 booster doses on days 0 and 3 , in the deltoid region.

Intramuscular administration of rabies vaccine is the gold standard recommended by the WHO. The subcutaneous route and intradermal routes have been explored. Subcutaneous routes have low seroconversion rates and a faster fall in antibody response [175]. The intradermal use of rabies vaccines is considered by the WHO as an acceptable alternative regimen as it requires less vaccine to produce a comparable degree of rabies protection $[82,86]$. Intradermal administration has become standard practice in a number of countries worldwide.

Vaccination by the intradermal route has become more popular as it requires a smaller volume of vaccine per dose, and is therefore cost-effective, and is as efficacious as the intramuscular route. This route is now accepted by WHO and has become standard practice in several countries [173, 176].

The WHO recommends 8 or 4 sites for intradermal immunization [177]. The intradermal route is contraindicated in the immunocompromised and those taking steroids or chloroquine.

\section{Vaccination after Re-exposure}

As per the WHO recommendation, 2 doses of any modern vaccine is required on days 0 and 3 for people who are reexposed to rabies and have taken a course of complete postexposure treatment with any of the modern cell culture vaccines any time in the past. There is no need for administration of rabies immunoglobulin [177].

\section{Conclusion}

Despite the optimism generated by the few human rabies survivors, survival continues to be an exceptionally rare occurrence. Moreover, most survivors continue to suffer from disabling neurological sequelae. However, paradoxically, rabies also has the unique distinction of being almost $100 \%$ preventable with timely and appropriate postexposure prophylaxis. Safe and efficacious biologicals for active (vaccines) and passive (HRIG/ERIG) immunization are available, which are extremely valuable in prevention and control of this dreaded disease.

Significant advances have been made in determining the pathobiology of this viral infection, but a number of questions still remain unanswered, not least the neuroanatomical and 
pathophysiological basis for the characteristic "hydrophobic" symptoms, curiously absent in animal models, unique to this viral infection. The mechanisms operative for its exclusive neurotropism, successful immune evasion, and almost fatal outcome without causing evident morphological alterations remain to be elucidated. The greatest stumbling block has been that despite animal models being available, the findings seen in vitro with laboratory strains of the virus do not reflect in vivo findings with wild-type strain. Until the modus operandi of the elusive rabies virus is decoded, treatment of this fatal encephalomyelitis will remain a distant dream.

Acknowledgments We acknowledge the technical help with the figures provided by Mr. K. Manjunath, Mrs Rajashakthi and Mr Shivaji Rao for the histological preparations, and Mrs. Kanakalakshmi and Mrs.Manjula Madan for their secretarial assistance. We also acknowledge the fruitful discussions with and encouragement received from Professor Dr. Alan C. Jackson [Department of Internal Medicine (Neurology), University of Manitoba] during his recent visit to our institute. This study is dedicated to the memory of Professor S.N. Madhusudana, Professor of Neurovirology, and long-term collaborator who spent his entire professional life researching rabies and who sadly passed away on 3 December 2015. This review is dedicated to his memory and his enormous research contributions to rabies viral pathogenesis, development of diagnostic kits, clinical trials on intradermal vaccines with cell culture vaccines, development of plant-based vaccines for rabies, and monoclonal antibodies for rabies.

Required Author Forms Disclosure forms provided by the authors are available with the online version of this article.

\section{References}

1. Jackson AC. Human disease. In: Jackson AC, Wunner WH, eds. Rabies. San Diego: Academic Press, 2007:309-333

2. Lanska DJ. Rabies virus, paralytic and classical. Lancet 1992; 339:809.

3. MMWR. Investigation of rabies infection in organ donor and transplant recipients - Alabama, Arkansas, Oklahoma, and Texas. MMWR Morb Mort Wkly Rep 2004;53:586-589.

4. Hemachudha T, Laothamatas J, Rupprecht CE. Human rabies: a disease of complex neuropathogenetic mechanisms and diagnostic challenges. Lancet Neurol 2002;1:101-109.

5. World Health Organization. WHO Expert consultation on rabies 2005. Technical report series 931 WHO Geneva 2005.

6. Meslin FX. Report on the status of rabies in the world 3rd international conference on rabies control in Asia 1996.

7. Sudarshan MK, Madhusudana SN, Mahendra BJ, et al. Int J Infect Dis 2007;11:29-35

8. Gamaleia N. Etude sur la rage paralytique chez L'homme. Ann Inst Pasteur (Paris) 1887;1:63-83

9. Pawan J. Paralysis as a clinical manifestation in human rabies. Ann Trop Med Parasitol 1939;33:21-29.

10. Banerjee AK, Chopra JS. Paralytic rabies. Neurol India 1974; 22: 83-86.

11. Chopra JS, Banerjee AK, Murthy JMK, Pal SR. Paralytic rabies. A clinico-pathological study. Brain 1980;103:789-802.

12. Jackson AC. Update on rabies. Curr Opin Neurol 2002;15:327331.
13. Jackson AC. Rabies virus infection: an update. J Neurovirol 2003;9:253-258

14. Hemachudha T, Wacharapluesadee S, Mitrabhakdi E, Wilde H. Pathophysiology of human paralytic rabies. Mini-review - the rabies virus. J Neurovirol 2005;11:93-100.

15. Fishbein D, Robinson L. Current concepts: rabies. N Engl J Med 1993;329:1632.

16. Messenger SL., Smits JS., Rupprecht CE. Emerging epidemiology of bat-associated cryptic cases of rabies in humans in the United States. Clin Infect Dis, 2002; 35: 738-747.

17. Winkler WG., Fashinell TR., Leffingwell L., Howard P., Conomy JP. Airborne rabies transmission in a laboratory worker. J Am Med Assoc 1973; 226: 1219-1221.

18. Gibbons RV. Cryptogenic rabies, bats, and the question of aerosol transmission. Ann Emerg Med 2002, 39, 528-536.

19. Houff SA, Burton RC, Wilson RW, et al. Human-to-human transmission of rabies virus by corneal transplant. N Engl J Med 1979;300:603-604.

20. Vetter JM, Frisch L, Drosten C, et al. Survival after transplantation of corneas from a rabies-infected donor. Cornea 2011;30:241-244.

21. Srinivasan A, Burton EC, Kuehnert MJ, et al.; Rabies in Transplant Recipients Investigation Team. Transmission of rabies virus from an organ donor to four transplant recipients. N Engl J Med 2005;352:1103-1111

22. Maier T, Schwarting A, Mauer D, et al. Management and outcomes after multiple corneal and solid organ transplantations from a donor infected with rabies virus. Clin Infect Dis 2010;50(8): 1112-1119.

23. Vora NM, Basavaraju SV, Feldman KA, et al.; TransplantAssociated Rabies Virus Transmission Investigation Team. Raccoon rabies virus variant transmission through solid organ transplantation. JAMA 2013;310:398-407.

24. Dutta JK. Rabies transmission by oral and other non-bite routes. J Indian Med Assoc 1998;96:359.

25. Hemachudha T. Rabies. In: PJ Vinken, GW Bruyn, HL Klawans, eds. Handbook of Clinical Neurology. Revised series, Amsterdam: Elsevier Science Publishers 1989:383-404.

26. Smith JS, Fishbein D, Rupprecht CE, et al. Unexplained rabies in three immigrants in the United States: a virologic investigation. $\mathrm{N}$ Eng J Med 1991;324:205-211.

27. Shankar SK, Mahadevan A, Sapico SD, Ghodkirekar MS, Pinto RG, Madhusudana SN. Rabies viral encephalitis with proable 25 year incubation period! Ann Indian Acad Neurol 2012;15:221223.

28. Charlton KM, Nadin-Davis S, Casey GA, Wandeler AI. The long incubation period in rabies: delayed progression of infection in muscle at site of exposure. Acta Neuropathol 1997;94:73-77.

29. Charlton KM, Casey GA. Experimental rabies in skunks: immunofluorescent and electron microscopic studies. Lab Invest 1979;41:36-44.

30. Charlton KM, Casey GA. Experimental rabies in skunks: persistence of virus in denervated muscle inoculation site. Can J Comp Med 1981;45:357-362.

31. Lentz TL, Burrage TG, Amith AL, Crick J, Tignor GH. Is the acetylcholine receptor a rabies virus receptor? Science 1982; 215:182-184.

32. Thoulouze MI, Lafage M, Schachner M, Hartmann U, Cremer H, Lafon M. The neural cell adhesion molecule is a receptor for rabies virus. J Virol 1998;72:7181-7190.

33. Moscoso LM, Cremer H, Sanes JR. Organization and reorganization of neuromuscular junctions in mice lacking neural cell adhesion molecule, tenascin-C, or fibroblast growth factor-5. J Neurosci 1998;18:1465-1477.

34. Polo-Parada L, Bose CM, Landmesser LT. Alterations in transmission, vesicle dynamics, and transmitter release machinery at 
NCAM-deficient neuromuscular junctions. Neuron 2001;32:815828

35. Tuffereau C, Banejean J, Blondel D, Kieffer B, Flamand A. Lowaffinity nerve-growth factor receptor (P75NTR) can serve as a receptor for rabies virus. EMBO J 1998;17:7250-7259.

36. Baer GM, Bellini WJ, Fishbein DB. Rhabdoviruses. In: BN Fields and DM Knipe, eds. Virology. New York: Academic Press 1990: 883-930.

37. Baer GM, Shaddock JH, Quirion R, et al. Rabies susceptibility and acetylcholine receptor. Lancet 1990;335:664-665.

38. Langevin C, Jaaro H, Bressanelli S, Fainziber M, Tuffereau C. Rabies virus glycoprotein (RVG) is a trimeric ligand for the Nterminal cysteine-rich domain of the mammalian p75 neurotrophin receptor. J Biol Chem 2002;277:37655.

39. Superti F, Hauttecoeur B, Morelec MJ, Goldoni P, Bizzini B, Tsiang $\mathrm{H}$. Involvement of gangliosides in rabies virus infection. J Gen Virol 1986;67:47-56.

40. Conti C, Superti F, Siang F. Membrane carbohydrate requirement for rabies virus binding to chicken embryo related cells. Intervirology 1986; 26:164-168.

41. Tang Y, Rampin O, Guiliano F, Ugolini G. Spinal and brain circuits to motorneurons of the bulbospongiosus muscle: retrograde transneuronal tracing with rabies virus. J Comp Neurol 1999;414: 167-192.

42. Kelly RM, Strick PL. Rabies as a transneuronal tracer of circuits in the central nervous system. J Neurosci Methods 2000;103:63-71

43. Steele JH, Fernandez PJ. History of rabies and Global Aspects. In: Baer GM (Ed), The Natural History of Rabies (2nd Edition),1991; pp1.

44. Kucera P, Dolivo M, Coulon P, Flamand A. Pathways of early propogation of virulent and avirulent rabies strains from eye to the brain. J Virol 1985; 55:158-162.

45. Tsiang H, Ceccaldi PE, Lycke E. Rabies virus infection and transport in human sensory dorsal root ganglia neurons. J Gen Virol 1991;72:1191-1194.

46. Lycke E, Tsiang H. Rabies virus infection of cocultured rat sensory neuron. J Virol 1987;61:2733-2741.

47. Tsiang H. Evidence for intraaxonal transport of fixed and street rabies virus. J Neuropathol Exp Neurol 1979;38:286-297.

48. Ceccaldi PE, Gillet JP, Tsiang H. Inhibition of the transport of rabies virus in the central nervous system. J Neuropathol Exp Neurol 1989;48:620-630.

49. Ceccaldi PE, Ermine A, Tsiang H. Continuous delivery of colchicine in the rat brain with osmotic pumps for inhibition of rabies virus transport. J Virol Methods 1990;28:79-83.

50. Tsiang H. Pathophysiology of rabies virus infection of the nervous system. Adv Virus Res 1993;42:375-412.

51. Van Harreveld A, Crowell H, Malhotra SK. A study of extracellular space in central nervous tissue by freeze-substitution. J Cell Biol 1965;25:117-137.

52. Charlton KM, Casey GA, Wandeler AI, et al. Early events in rabies virus infection of the central nervous system in skunks (Mephitis mephitis). Acta Neuropathol 1996;91:89-98.

53. Baer GM, Shanthaveerappa TR, Bourne GH. The pathogenesis of street virus rabies in rats. Bull WHO 1968;38:119-125.

54. Bylenga G, Haeney T. Post exposure local treatment of mice infected with rabies with two axonal inhibitors colchicines and vinblastine. J Gen Virol 1978;50:433-435.

55. Prevosto V, Graf W, Ugolini G. Cerebellar inputs to intraparietal cortex areas LIP and MIP: functional frameworks for adaptive control of eye movements, reaching, and arm/eye/head movement coordination. Cerebral Cortex (New York, NY). 2010;20:214228.

56. Ugolini G. Specificity of rabies virus as a transneuronal tracer of motor networks: transfer from hypoglossal motor neurons to connected second-order and higher order central nervous system cell groups. J Comp Neurol 1995;365:457-480.

57. Hirokawa N, Takemura R. Molecular motors and mechanisms of directional transport in neurons Nat Rev Neurosci 2005;6:201-214

58. Bauer A, Nolden T, Schröter J, et al. Anterograde glycoproteindependent transport of newly generated rabies virus in dorsal root ganglion neurons. J Virol 2014;88:14172-14183.

59. Iwasaki Y, Clark HF. Cell to cell transmission of virus in the central nervous system II. Experimental rabies in the mouse. Lab Invest 1975;33:391-399.

60. Iwasaki Y, Liu DS, Yamamoto T, Konno H. On the replication and spread of rabies virus in the human central nervous system. J Neuropathol Exp Neurol 1985;44:185-195.

61. Dean DJ, Evans WM, McClure RC. Pathogenesis of rabies. Bull WHO 1963;29:803-811.

62. Ugolini G. Rabies virus as a transneuronal tracer of neuronal connections. Adv Virus Res 2011;79:165-202

63. Jackson AC, Ye H, Phelan CC, et al. Extraneural organ involvement in human rabies. Lab Invest 1999;79:945-951

64. Jogai S, Radotra BD, Banerjee AK. Rabies viral antigen in extracranial organs: a post-mortem study. Neuropathol Appl Neurobiol 2002;28:334-338.

65. Etessami R, Conzelmann KK, Fadai-Ghotbi B, Netelson B, Tsiang H, Ceccaldi PE. Spread and pathogenic characteristics of a G-deficient rabies virus recombinant: an in vitro and in vivo study. J Gen Virol 2000;81:2147-2153.

66. Yan X, Mohankumar PS, Dietzschold B, Schnell M, Fu ZF. The rabies virus glycoprotein determine the distribution of different rabies virus strains in the brain. J Neurovirol 2002;8:345-352.

67. Mazarakis ND, Azzouz M, Rohll JB, et al. Rabies virus glycoprotein pseudotyping of lentiviral vectors enables retrograde axonal transport and access to the central nervous system after peripheral delivery. Hum Mol Genet 2001;10:2109-2121.

68. Wunner WH. Rabies virus. In: Jackson AC, Wunner WH, eds. Rabies. New York: Academic Press 2002:23-77.

69. Poisson N, Real E, Gaudin Y, et al. Molecular basis for the interaction between rabies virus phosphoprotein $\mathrm{P}$ and the dynein light chain LC8: dissociation of dynein-properties and transcriptional functionality of P. J Gen Virol 2001;82:2691-2696.

70. Jacob Y, Badrane H, Ceccaldi PE, Tordo N. Cytoplasmic dynein LC8 interacts with lyssavirus phosphoprotein. J Virol 2000;74: 10217-10222.

71. Raux H, Flamand A, Blondel D. Interaction of the rabies virus $P$ protein with the LC8 dynein light chain. J Virol 2000;74:1021210216.

72. Mebatsion T. Extensive attenuation of rabies virus by simultaneously modifying the dynein light chain binding site in the $\mathrm{P}$ protein and replacing Arg333 in the G protein. J Virol 2001;75: 11496-11502.

73. Hernáez B(1), Tarragó T, Giralt E, Escribano JM, Alonso C. Small peptide inhibitors disrupt a high-affinity interaction between cytoplasmic dynein and a viral cargo protein. J Virol 2010;84:1079210801.

74. Moseley GW, Lahaye X, Roth DM, et al. Dual modes of rabies Pprotein association with microtubules: a novel strategy to suppress the antiviral response. J Cell Sci 2009;122:3652-3662

75. Hirosue S, Senn K, Clément N, et al. Effect of inhibition of dynein function and microtubule-altering drugs on AAV2 transduction. Virology 2007;367:10-18.

76. Hemachudha T. Human rabies: clinical aspects, pathogenesis and potential therapy. In: CE Rupprecht, B Dietzschold, H Koprowski, eds. Lyssaviruses. New York: Springer-Verlag, Berlin, Germany 1994; 187; 121-144.

77. Laothamatas J, Hemachudha T, Mitrabhakdi E, Wannakrairot P, Tulayadaechanont S. MR imaging in human rabies. AJNR Am J Neuroradiol 2003;24:1102-1109. 
78. Mitrabhakdi E, Shuangshoti S, Wannakrairot P, et al. Difference in neuropathogenetic mechanisms in human furious and paralytic rabies. J Neurol Sci 2005; 238:3-10.

79. Hemachudha T, Panpanich T, Phanuphak P, Manutsathit S, Wilde H. Immune activation in human rabies. Trans R Soc Trop Med Hyg 1993; 87:106-108.

80. Sriwanthana B, Hemachuda T, Griffin DE, Manustsathit S, Tweardy D, Phanuphak P. Lymphocyte subsets in human encephalitic and paralytic rabies. Acta Neurol Scand 1989;80:287-289.

81. Hemachudha T, Phanuphak P, Sriwanthana B, et al. Immunologic study of human encephalitic and paralytic rabies. Preliminary report of 16 patients. Am J Med 1988;84:673-677.

82. Tangchai P, Vejjajiva A. pathology of the peripheral nervous system in human rabies:a study of nine cases. Brain 1971;94:299306.

83. Hemachudha T, Wacharapluesadee S, Lumlertdaecha B, et al. Sequence analysis of rabies virus in humans exhibiting encephalitic or paralytic rabies. J Infect Dis 2003;188:960-966.

84. Gadre G, Satishchandra P, Mahadevan A, et al. Rabies viral encephalitis: clinical determinants in diagnosis with special reference to paralytic form. J Neurol Neurosurg Psychiatry 2010;81:812820 .

85. Mahadevan A, Suja MS, Madhusudana SN, Patil S, Satishchandra P. Guillain Barré syndrome versus paralytic rabies - at the spinal level. 2nd International Conference of Rabies in Asia (RIA) Foundation. Sept 2009 [Abstract].

86. Ogawara K, Kuwabara S, Mori M, Hattori T, koga M, Yuki N. Axonal Guillain-Barré syndrome: relation to anti-ganglioside antibodies and Campylobacter jejuni infection in Japan. Ann Neurol 2000;48:624-631.

87. Sheikh KA, Ramos-Alvarez M, Jackson AC, Li CY, Asbury AK, Griffin JW. Overlap of pathology in paralytic rabies and axonal Guillain-Barre syndrome. Ann Neurol 2005;57:768-772.

88. Gorson KC, Rooper A, Muriello M, Blair R. Prospective evaluation of MRI lumbosacral nerve root enhancement in acute Guillain-Barré syndrome. Neurology 1996;47:813-817.

89. Hemachudha T, Mitrabhakdi E. Rabies. In: Davis L, Kennedy PGE, eds. Infectious diseases of the nervous system. Oxford: Butterworth-Heinemann 2000:404-444.

90. Goswami U, Shankar SK, Channabasavanna SM, Chattopadhyay A. Psychiatric presentations in rabies. A clinico-pathologic report from South India with a review of literature. Trop Geogr Med $1984 ; 36: 77-81$

91. Smart NL, Charlton KM. The distribution of challenge virus standard rabies virus versus skunk street rabies virus in the brains of experimentally infected skunks. Acta Neuropathol 1992;84:501508.

92. Madhusudana SN. Rabies presenting with sexual manifestations. J Indian Med Assoc 1988;86:43-44

93. Suja MS, Mahadevan A, Madhusudana SN, Shankar SK. Is death in rabies related to specific neuroanatomical pathology? - A study in human, canine and rodent brains. 2nd International Conference of Rabies in Asia (RIA) Foundation. Sept 2009 [Abstract].

94. Perl DP, Good PF. The pathology of rabies in the central nervous system. In: GM Baer (ed). 2nd edn, The Natural History of Rabies. CRC Press: Boca Raton, FL 1991:163-190.

95. Iwasaki Y, Tobita M. Pathology. In: Jackson AC, Wunner WH, eds. Rabies. Academic Press: San Diego, CA 2002:283-306.

96. Fu ZF, Jackson AC. Neuronal dysfunction and death in rabies virus infection. J Neurvirol 2005;11:101-106

97. Iwata M, Komori S, Unno T, Minamoto N, Ohashi H. Modification of membrane currents in mouse neuroblastoma cells following infection with rabies virus. Br J Pharmacol 1999;126: 1691-1698.

98. Tsiang H. Neuronal function impairment in rabies infected rat brain. J Gen Virol 1982;61:277-281.
99. Koprowski H, Zheng YM, Heber-Katz E, et al. In vivo expression of inducible nitric oxide synthase in experimentally induced neurologic disease. Proc Natl Acad Sci U S A 1993;90: 3024-3027.

100. Hooper DC, Ohnishi ST, Kean R, Numagami Y, Dietzschold B, Koprowski H. Local nitric oxide production in viral and autoimmune diseases of the central nervous system. Proc Natl Acad Sci U S A 1995; 92:5312-5316.

101. Griffin DE, Hardwick JM. Perspective: Virus infections and the death of neurons. Trends Microbiol 1999;7:155-160.

102. Fazakerley JK, Allsopp TE. Programmed cell death in virus infections of the nervous system. Curr Top Microbiol Immunol 2001; 253:95-119.

103. Murphy FA. Rabies pathogenesis. Arch Virol 1977; 54:279-297.

104. Jackson AC, Park H. Apoptotic cell death in experimental rabies in suckling mice. Acta Neuropathol 1998;95:159-164.

105. Morimoto K, Hooper DC, Spitsin S, Koprowski H, Dietzschold B. Pathogenicity of different rabies virus variants inversely correlates with apoptosis and rabies virus glycoprotein in infected primary neuron cultures. J Virol 1999;73:510-518.

106. Reid JE, Jackson AC. Experimental rabies virus infection in Artibeus jamaicensis bats with CVS-24 variants. J Neurovirol 2001; 7: 511-517.

107. Park Chun-Ho, Kondo M, Inoue S, et al. The Histopathogenesis of paralytic rabies in six week old C57BL/6J mice following inoculation following inoculation of the CVS-11 strain into the right triceps surae muscle. J Vet Med Sci 2006;68:589-595.

108. Theerasurakarn S, Ubol S. Apoptosis induction in brain during the fixed strain of rabies virus infection correlates with onset and severity of illness. J Neurovirol 1998;4:407-414

109. Jackson AC, Rasalingam P, Weli SC. Comparative pathogenesis of recombinant rabies vaccine strain SAD-L16 and SAD-D29 with replacement of Arg333 in the glycoprotein after peripheral inoculation of neonatal mice: less neurovirulent strain is a stronger inducer of neuronal apoptosis. Acta Neuropathol 2006;111:372378.

110. Ubol S, Kasisith J. Reactivation of Nedd-2, a developmentally down-regulated apoptotic gene, in apoptosis induced by a street strain of rabies virus. J Med Microbiol 2000;49:1043-1046.

111. Yan X, Mohankumar PS, Dietzschold B, Schnell MJ, Fu ZF. The rabies virus glycoprotein determines the distribution of different rabies virus strains in the brain. J Neurovirol 2001;8:345-352.

112. Jackson AC, Randle E, Lawrance G, Rossiter JP. Neuronal apoptosis does not play an important role in human rabies encephalitis. J Neurovirol 2008;14:368-375.

113. Suja MS, Mahadevan A, Madhusudana SN, Shankar SK. Role of apoptosis in rabies viral encephalitis: a comparative study in mice, canine, and human brain with a review of literature. Patholog Res In. 2011;2011:374286.

114. Scott CA, Rossiter JP, Andrew RD, Jackson AC. Structural abnormalities in neurons are sufficient to explain the clinical disease and fatal outcome of experimental rabies in yellow fluorescent proteinexpressing transgenic mice. J Virol 2008; 82:513-521.

115. Kammouni W, Wood H, Saleh A, Appolinario CM, Fernyhough P, Jackson AC. Rabies virus phosphoprotein interacts with mitochondrial Complex I and induces mitochondrial dysfunction and oxidative stress. J Neurovirol 2015;21:370-382.

116. Dacheux L, Reynes JM, Buchy P, et al. A reliable diagnosis of human rabies based on analysis of skin biopsy samples. Clin Infect Dis 2008:47:1410-1417.

117. Hemachudha T., Wacharapluersadee S. Antemortem diagnosis of human rabies. Clin Infect Dis 2004;39:1085-1086.

118. Madhusudana SN, Sukumaran SM. Antemortem diagnosis and prevention of human rabies. Ann Ind Acad Neurol 2008;11:3-12.

119. Antemortem testing. Rabies. Available at: http://www.cdc. gov/rabies/specific_groups/doctors/ante_mortem.html 
120. World Health Organization. Expert Consultation on Rabies. 1. Report. Geneva: WHO Tech. Rep. Series 931, 2004.

121. Hooper DC., Morimoto K., Bette M., Weihe M., Koprowski H., Dietshchold B. Collaboration of antibody and inflammation in the clearance of rabies virus from the CNS. J Virol 1998;72:37113719.

122. Crepin P, Audry L, Rotivel Y, Gacoin A, Caroff C, Bourhy H. Intravitam diagnosis of human rabies by PCR using saliva and cerebrospinal fluid. J Clin Microbiol 1998;36:1117-1121

123. Macedo CI, Carnieli PJ, Brandao PE, et al. Diagnosis of human rabies cases by polymerase chain reaction of neck-skin samples. Braz J Infect Dis 2006;10:341-345.

124. Koch KJ., Sagartz JW., Davidson D., Lawhaswahs K. Diagnosis of human rabies by cornea test. Am J Clin Pathol 1975;63:509515 .

125. Wacharapluesadee S, Hemachudha T. Ante mortem postmortem diagnosis of rabies using nucleic acid amplification tests. Expert Rev Mol Diagn 2010;10:207-218.

126. Mani RS, Madhusudana SN. Laboratory diagnosis of human rabies: recent advances. ScientificWorldJournal 2013;2013:569712

127. Mani RS, Madhusudana SN, Mahadevan A, Reddy V, Belludi AY, Shankar SK. Utility of real-time Taqman PCR for antemortem and postmortem diagnosis of human rabies. J Med Virol 2014;86: 1804-1812.

128. Mani RS, Anand AM, Madhusudana SN. Human rabies in India: an audit from a rabies diagnostic laboratory. Trop Med Int Health 2016;21:556-563.

129. Montano Hirose JA, Bourhy H, Sureau P. Retro-orbital route for brain specimen collection for rabies diagnosis. Vet Rec 1991;129: 291-292.

130. Tong TR, Leung KM, Lee KC, Lam AW. Trucut needle biopsy through superior orbital fissure for the diagnosis of rabies. Lancet 1999;354:2137-2138.

131. Sudarsanam TD, Chacko G, David RD. Postmortem trucut transnasal brain biopsy in the diagnosis of encephalitis. Trop Doct 2008;38:163-165.

132. Sow PS, Diop BM, Ndour CT, et al. La ponction aspiration sousoccipitale: technique de prélèvement cérébral post-mortem pour le diagnostic virologique de 1 encéphalite rabique humaine à Dakar. Med Mal Infect 1996;26:534-536.

133. Neizgoda M, Rupprecht CE. Standard operating procedure for the direct rapid immunohistochemistry test for the detection of rabies virus antigen. Atlanta, GA: National Laboratory Training Network Course; US Department of Health and Human Services; Centers for Disease Control and Prevention; 2006

134. Binghem J., Van Der Merwe M. Distribution of rabies antigen in infected material: determining the reliability of different regions of the brain for the rabies fluorescent antibody test. J Virol Methods 2002;101:85-94

135. Venugopal AK, Ghantasala SS, Selvan LD, et al. Quantitative proteomics for identifying biomarkers for Rabies. Clin Proteomics. 2013;10:3.

136. O'Sullivan A, Willoughby RE, Mishchuk D, et al. Metabolomics of cerebrospinal fluid from humans treated for rabies. J Proteome Res 2013;12:481-490.

137. Centers for Disease Control and Prevention. Human rabies prevention-United States, 1999: recommendations of the Advisory Committee on Immunization Practices (ACIP). MMWR Morb Mortal Wkly Rep 1999;48(RR-1):1-21.

138. Dean D, Baer G, Thowpson W. Studies on the local treatment of rabies infected wounds. Bull World Health Organ 1963;28:477.

139. World Health Organization. Guidelines for post exposure treatment. 8th Report of the WHO Expert Committee on Rabies. Geneva: WHO, 2000.

140. Jackson AC, Warrell MJ, Rupprecht CE, et al. Management of rabies in humans. Clin Infect Dis 2003;36:60-63.
141. Willoughby RE, Rotar MM, Dohnau HL, et al. Recovery of a patient from clinical rabies-Wisconsin, 2004. MMWR Morb Mortal Wkly Rep 2005;53:1171-1173.

142. Hunter M, Johnson N, Hedderwick S, et al. Immunovirological correlates in human rabies treated with therapeutic coma. J Med Virol 2010;82:1255-1265.

143. Pue HL, Turabelidze G, Patrick S, et al. Human Rabies. Missouri, 2008. MMWR Morb Mortal Wkly Rep 2009;58:1207-1209.

144. Hemachudha T, Sunsaneewitayakul B, Desudchit T. Failure of therapeutic coma and ketamine for therapy of human rabies. $\mathrm{J}$ Neurovirol 2006;12:407-409.

145. McDermid RC, Saxinger L, Lee B. Human rabies encephalitis following bat exposure: failure of therapeutic coma. Can Med Assoc J 2008; 178:557-561.

146. Jackson AC. Update on rabies diagnosis and treatment. Curr Infect Dis Rep 2009;11:296-301.

147. Jackson AC. Therapy of human rabies. In: Jackson AC (ed.), Rabies-Scientific Basis of Disease and its Management (3rd edn). Academic Press: Oxford, 2013; 575-585.

148. Dietzschold B, Kao M, Zheng YM, et al. Delineation of putative mechanisms involved in antibody-mediated clearance of rabies virus from the central nervous system. Proc Natl Acad Sci U S A 1992;89:7252-7256.

149. Lockhart BP, Tordo N, Tsiang H. Inhibition of rabies virus transcription in rat cortical neurons with the dissociative anesthetic ketamine. Antimicrob Agents Chemother 1992; 36:1750-1755.

150. Tam RC., Lau JY., Hong Z. Mechanisms of action of ribavirin in antiviral therapies. Antivirol Chem Chemother 2001;12:261-272.

151. Bussereau F, Ermine A. Effects of heteropolyanions and nucleoside analogues on rabies virus: in vitro study of syntheses and viral production. Ann Virol (Inst Pasteur) 1983;134E:487-506.

152. Bussereau F, Picard M, Blancou J, Sureau P. Treatment of rabies in mice and foxes with antiviral compounds. Acta Virol 1988;32:3349.

153. Warrell MJ, White NJ, Looareesuwan S, et al. Failure of interferon alfa and tribavirin in rabies encephalitis. BMJ 1989;299:830-833.

154. Enright JB, Franti CE, Frye FL, Behymer D. The effects of corticosteroids on rabies in mice. Can J Microbiol 1970;16:667-675.

155. Basgoz N., Frosch MP. Case 21-1998. A 32-year-old woman with pharyngeal spasms and paresthesias after a dog bite. N Engl J Med 1998;339:105-112.

156. Dietzschold B, Morimoto K, Hooper DC, Smith JS, Rupprechet $\mathrm{CE}$, Koprowski H. Genotypic and phenotypic diversity of rabies virus variants involved in human rabies: implications for postexposure prophylaxis. J Hum Virol 2000;3:50-57.

157. CDC. Rabies in a laboratory worker-New York. MMWR 1977;26:183-184.

158. Hattwick MA, Weis TT, Stechschulte CJ, Baer GM, Gregg MB. Recovery from rabies. A case report. Ann Intern Med 1972;76: 931-942.

159. Porras C, Barboza JJ, Fuenzalida E, Adaros HL, Oviedo AM, Furst J. Recovery from rabies in man. Ann Intern Med 1976;85: 44-48.

160. Alvarez L, Fajardo R, Lopez E, et al. Partial recovery from rabies in a nine-year-old boy. Pediatr Infect Dis J 1994;13:1154-1155.

161. Madhusudana SN, Nagaraj D, Uday M, Ratnavalli E, Kumar MV. Partial recovery from rabies in a six-year-old girl. Int J Infect Dis 2002;6:85-86.

162. de Souza A, Madhusudana SN. Survival from rabies encephalitis. J Neurol Sci 2014;339:8-14.

163. Karande S, Muranjan M, Mani RS, et al. Atypical rabies encephalitis in a six-year-old boy: clinical, radiological, and laboratory findings. Int J Infect Dis 2015;36:1-3.

164. Netra, et al. Unique clinical and imaging findings in a first ever documented PCR positive rabies survival patient: a case report. J Clin Virol 2015;70:83-88. 
165. Kumar KV, Ahmad FM, Dutta V. Pituitary cachexia after rabies encephalitis. Neurol India 2015;63:255-256.

166. Emmons RW, Leonard LL, DeGenaro F, et al. A case of human rabies with prolonged survival. Intervirology 1973;1:60-72.

167. Gode GR, Raju AV, Jayalakshmi TS, Kaul HL, Bhide NK. Intensive care in rabies therapy: clinical observations. Lancet 1976;2:6-8.

168. Sandhyamani S, Roy S, Gode GR, Kalla GN. Pathology of rabies: a light and electron microscopic study with particular reference to changes in cases with prolonged survival. Acta Neuropathol 1981;54:247-251.

169. Mejid J, Appolinario CM, Mazzini AM, Almeida MF. Evaluation of cytokines concentration and percentage of survival of rabies virusinfected mice submitted to anti-rabies Vero-cell propagated vaccine and $P$. acnes. Vet Immunol Immunopathol 2006;114:192-196.

170. Ubol S, Sukwattanapan C, Maneerat Y. Inducible nitric oxide synthase delays death of rabies virus. J Med Microbiol 2001;50: 238-242.

171. Camelo S, Lafage M, Lafon M. Absence of the p55 Kd TNF- $\alpha$ receptor promotes survival in rabies virus acute encephalitis. J Neurovirology 2000;6:507-518.
172. Lafon M. Immunology. In: Jackson AC, Wunner WH, editors. Rabies. San Diego, CA: Academic Press; 2002. p. 351-369.

173. World Health Organization, WHO Expert Consultation on Rabies. Second report, World Health Organization Technical Report Series 982, 2013.

174. Strady C, Hung Nguyen V, Jaussaud R, et al. Pre-exposure rabies vaccination: strategies and cost-minimization study. Vaccine 2001;19:1416-1424

175. National Advisory Committee on Immunization. Update on rabies vaccine. Can Commun Dis Rep 2005;1:1-8.

176. Madhusudana SN, Mani RS. Intradermal vaccination for rabies prophylaxis: conceptualization, evolution, present status and future. Expert Rev Vaccines 2014;13:641-655.

177. World Health Organization (WHO). WHO recommendations on rabies post-exposure treatment and the correct technique of intradermal immunization against rabies. Geneva: World Health Organization; 1997. WHO/EMC/ZOO/96.6, 1-23. Available at: http://www.who.int/emc-documents/rabies/docs/whoemczoo966. pdf. Accessed, November 22, 2002. 